\title{
Why Nature is Good to Think, Feel and Live by in the Joban Divine Speeches: Some Psychological Perspectives on the Worth of Exposure to Wild Animals ${ }^{1}$
}

\author{
HENDRIK VIVIERS (UNIVERSITY OF JOHANNESBURG)
}

\begin{abstract}
The Biophilia Hypothesis has emphasised our innate attraction to the natural world, where we come from. Modern psychologies (e.g. developmental, emotional and environmental) have built on this and have highlighted the worth of being exposed to nature. Developmentally it has been shown how exposure to nature enhances cognitive, emotional and moral development in discovering the self. Emotionally it is especially the emotion of "awe" (wonderment born out of vastness and difficult to grasp) that leads to ego-transcendence, humbleness and oneness with nature. From the environmental perspective the fascination with the non-human environment can be restorative, calming and leading to contemplation and reflection. The pre-scientific Joban poet has intuitively grasped these emphases of modern research and celebrated nature and wild animals (unique in the $H B$ ) as good to think, feel and live by. The main character Job, however, seems not to have accepted this.
\end{abstract}

KEYWORDS: Job, divine speeches, wild animals, biophilia, psychology, awe, ego-transcendence, restoration.

\section{A INTRODUCTION}

The first part of the title of this article, "why nature is good to think, feel and live by," is intended to place ourselves in the midst of the field of psychology. Different psychologies, each with its unique contribution, have focused on the worth of being exposed to wild nature, for instance developmental, emotional and environmental psychology. Most of them acknowledge and depart from the

* Article submitted: 23/01/2017; peer-reviewed: 20/02/2017; accepted: 10/05/2017. Hendrik Viviers, "Why Nature is Good to Think, Feel and Live by in the Joban Divine Speeches: Some Psychological Perspectives on the Worth of Exposure to Wild Animals," Old Testament Essays 30/2 (2017): 503-524, doi: http:// dx.doi.org/10.17159 /2312-3621/2017/v30n2a18

1 Dedicated to Prof. Sakkie Spangenberg, a close colleague and friend for more than three decades. Amongst the many interests that we share it is especially eco-theology that is up front. I am grateful to Sakkie, who many years ago, introduced me to the wellknown "Earth Bible Series" (of Norman Habel, et al.), that has ever since kept my interest in this field alive. 
Biophilia Hypothesis that has aptly highlighted our innate attraction to the natural world. Developmentally it has been shown how exposure to nature enhances cognitive, emotional and moral development in discovering the self, a continuous process from childhood into adulthood. Emotionally it has been shown that the emotion of "awe" (wonderment born out of vastness and difficult to grasp) especially leads to ego-transcendence, humbleness and oneness with nature, and the feeling that the world is good in both its enlightening and terrifying effects. Environmentally, it has been discovered that the fascination with the non-human environment can be restorative, calming and leading to contemplation and reflection. In what follows more will be said on the contributions of each of these fields. The insights of each field will then be used as a "lens" to appreciate the portrayal of the wild animals in the Joban divine speeches.

Why Job? David Clines provides the answer with his recap of the appreciation of the wild animals in Job as "Divine Delight/Poet's Pleasure." 2 Delight, pleasure or joy are emotional terms that immediately evoke the psychological meaningfulness of being exposed to nature and wild animals. Clines conjures this, although not elaborating on the "psychology" of nature in the speeches specifically, what this article endeavours to do. Clines also indicates that in the divine speeches Job is taken on a creational tour, where (hitpael) hithallāktā, "have you walked about..." (38:16), has the connotation of the "touristic."3 Similar as a visit to the wilds today, this is meant to do Job "good," to broaden his insights and to restore and enrich him. Whether Job finally accepts this remains somewhat of an open and difficult question, but the reader of these speeches is intuitively lured to accept that exposure to the natural world is good.

It is time to investigate whether the author of Job has a similar (intuitive) appreciation for wild animals and nature generally, even as a child of his time, before modern psychological science laid this bare in an empirical way.

\section{B THE BIOPHILIA HYPOTHESIS AND THE WILD ANIMALS OF THE DIVINE SPEECHES (OR: THE INNATE BOND WITH NATURE)}

The well-known Harvard biologist Edward O. Wilson, the founder of the Biophilia Hypothesis, describes it as "the innately emotional affiliation of human

2 David J. A. Clines, "The Worth of Animals in the Divine Speeches of the Book of Job," in Where the Wild Ox Roams: Biblical Essays in Honour of Norman C. Habel, HBM 59, ed. Alan H. Cadwallader and Peter L. Trudinger (Sheffield: Sheffield Phoenix Press, 2013), 108.

3 David J. A. Clines, Job 38-42, WBC 18B (Nashville: Thomas Nelson, 2011), 1106. 
beings to other living organisms." 4 There is a natural attraction, an almost spontaneous attention to other, non-human animals, especially the big vertebrates that catch the eye, confirming the intimate bond between us and the rest of living nature. More people visit zoos and wild parks annually than those attending big sports events. ${ }^{5}$ We recognise ourselves in the animals that we see and learn from them. This innate "love for life" (bio philia) seems to be biologically based (genetically) and culturally shaped, for as long as humans and their hominid predecessors have been around the past few million years. The genetic code that we share with other life forms goes back even further, more or less 1,8 billion years when life evolved from the primeval "soup" of single-celled eukaryotes and bacteria and almost "big-banged" (over lengthy evolutionary time obviously) into the mind-boggling richness of bio-diversity that we know of and still need to discover. ${ }^{6}$ In a single gram of forest soil there are four to five thousand species of bacteria consisting of ten million individual organisms: "More organisation and complexity exist in a handful of soil than on the surfaces of all the other planets combined." 7

With the term "innate" Wilson means learning rules or "prepared learning" that became established in our genes as we co-evolved with other lifeforms over aeons. This happened in a bio-centric and not a machine-centred world as we are inclined to believe, finding ourselves in our modern technological environment. The natural curiosity for learning became established to help us adapt continuously (and become better adapted) and find our survival niche in our living environments. These learning rules are "energised" so to speak by emotions of attraction or aversion, for instance, "Human beings are

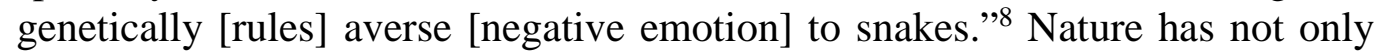
become the living space and means for our physical survival, its utilitarian value, but also the space and means where and through which we experience selffulfilment. Nature has aesthetic and spiritual value, which have become so part of the human make-up that we cannot live without it. And therefore Wilson ${ }^{9}$ rightly asks what is going to happen to the human psyche if we lose the rich biodiversity of (wild) nature.

4 Edward O. Wilson, "Biophilia and the Conservation Ethic," in The Biophilia Hypothesis, ed. Stephen R. Kellert and Edward O. Wilson (Washington: Shearwater Books, 1993), 31.

5 Wilson, "Biophilia and the Conservation Ethic," 32.

6 How remarkable is Charles Darwin's insight that long before the founding of the science of genetics, he realised that all life derived from a single ancestor.

7 Wilson, "Biophilia and the Conservation Ethic," 39.

8 Wilson, "Biophilia and the Conservation Ethic," 33.

9 Wilson, "Biophilia and the Conservation Ethic," 35. 
Expanding on Wilson's insights, the psychologist Stephen R. Kellert ${ }^{10}$ emphasises the founding of human identity and personal fulfilment through the exposure to nature. The presence of nature, especially for human emotional, cognitive, aesthetic and spiritual development, exceeds its worth for physical survival only. He has devised nine categories of affinities or valuations of nature that have become universally expressed. Different cultures might have differing views on specific animals but in general there is agreement on the following values of nature. ${ }^{11}$ Myers and others ${ }^{12}$ argue that attitudes are partly affective and therefore also add the appropriate emotion(s) that accompany these different values (inserted in brackets after each value): utilitarian (security) - indicates the material value that nature provides for humans' physical needs, such as food, medicine, clothing, tools and so on; naturalistic (curiosity) - indicative of the sense of fascination, wonder and awe when experiencing the diversity and complexity of nature. There is also a natural curiosity about nature, to learn from it to enhance improved adaptation. Furthermore, nature provides restoration from tension and stress and improves creativity and reflectivity; ${ }^{13}$ ecologisticscientific (cognitive satisfaction) - whereas science has a more mechanistic approach to nature and ecology more holistically, both point to the systematic, empirical study of nature to lay bare its "organizational structure and complexity."14 The knowledge thus obtained leads to respect and fascination with the complex, wondrous world of nature; aesthetic (inspiration and peace) nature has a powerful aesthetic effect on people evoking awe: "Unlike ... obscure organisms, the aesthetic response is typically directed at larger, charismatic megavertebrate species." ${ }^{15}$ Kaplan and Kaplan ${ }^{16}$ also point out that aesthetics comprises more than "enjoyment" but notably has to do with survival choices, for instance the attractions of "green" (indicating the life-force) and "water" become a guide to humans to choose sustaining habitats; symbolic (communication) - it is well-known from myths, fairy tales, stories, legends and fables (e.g. children's books on animals), how animals are often used to symbolise some human trait or an abstract idea. It enhances "selfhood, identity,

10 Stephen R. Kellert, “The Biological Basis for Human Values of Nature,” in The Biophilia Hypothesis, ed. Stephen R. Kellert and Edward O. Wilson (Washington: Shearwater Books, 1993), 42.

11 Kellert, "Biological Basis," 44-59.

12 Olin E. Myers, Jr., Carol D. Saunders, and Andrej A. Birjulin, "Emotional Dimensions of Watching Zoo Animals: An Experience Sampling Study Building on Insights from Psychology,” Curator 47 (2004): 301.

13 Rachel Kaplan and Stephen Kaplan, The Experience of Nature: A Psychological Perspective (Cambridge: Cambridge University Press, 1989).

14 Kellert, "Biological Basis," 48. Kellert here also refers to Wilson who notes that the genetic description of a mouse would fill every page of the Encyclopedia Britannica since its inception in the 1750's to today.

15 Kellert, "Biological Basis,” 49.

16 Kaplan and Kaplan, Experience of Nature, 9. 
expressive thought and abstraction";17 humanistic (love) - implies "love for nature" and becomes expressed inter alia in the human - animal companion relationship where companion animals are anthropomorphised as substitute humans. Early domestication of wild animals and the utilisation of their knowledge and skills could also have contributed to the evolutionary fitness of their owners; ${ }^{18}$ moralistic (reverence and kinship) - this value has to do with the ethical responsibility towards nature, accompanied by a reverence for its intrinsic worth; ${ }^{19}$ dominionistic (mastery) - has to do with mastering the natural world and although nowadays frowned upon, it made good sense in the early struggles for survival; negativistic (fear, aversion) - early survival was most probably also driven by fear, aversion and antipathy towards some elements of nature, for instance "to fear and avoid ... reptiles such as snakes and anthropods such as spiders and various biting and stinging invertebrates." ${ }^{20}$ Burke aptly states that the experience of the sublime through nature rests on terror/fear as its "ruling principle," 21 and attractively captured in the English word "terrific." And on a similar note as Wilson, fearing the impoverishing of the human mind if (wild) nature disappears, Kellert ${ }^{22}$ concludes that the exposure to nature is not a luxury for only an interested (nowadays elitist) few, but is imperative for the mental well-being of all humanity.

Do the Joban poet and his God character in the divine speeches intuitively share this "love for nature" emphasised by the Biophilia Hypothesis? Does he precede science as a keen and wise observer of the richness of the natural world and sensing the intimate bond with nature? The answer is clearly yes with a markedly "divine intimacy" and delight for the whole of God's created universe. ${ }^{23}$ Clines $^{24}$ comments on a sort of inclusio between the beginning of the animal descriptions (38:39-41; lion and raven preying) and the end (39:26-30; hawk and vulture as birds of prey) but without emphasising a specific animal. The poet's depiction of the different kinds strongly emphasise his appreciation

17 Kellert, "Biological Basis," 52. He also notes that children intuitively choose to play with real animals instead of an animal toy.

18 Kellert, "Biological Basis,” 53.

19 See also Norman C. Habel, Finding Wisdom in Nature: An Eco-Wisdom Reading of the Book of Job, EBCS 4 (Sheffield: Sheffield Phoenix Press, 2014), 5, who, from an eco-theological approach, emphasises the same value.

20 Kellert, "Biological Basis," 57. He also makes the interesting remark that invertebrates look like "monsters" (p. 52).

21 Edmund Burke, A Philosophical Inquiry into the Origin of our Ideas of the Sublime and the Beautiful, ed. James T. Boulton (London: Routledge and Kegan Paul, 1967), 58, 91. Beauty, the opposite of the sublime, is that which causes love, attraction (but not lustful or desirable) and tenderness.

22 Kellert, "Biological Basis," 60, cites René DuBos who says "the cult of wilderness is not a luxury; it is a necessity for the preservation of mental health."

23 Clines, Job 38-42, 1090.

24 Clines, Job 38-42, 1094. 
for the rich diversity of animal life. ${ }^{25}$ Furthermore, even though the poet anthropomorphises both the cosmos and the animals he describes, ${ }^{26}$ this is not the kind of "bambification" that one often finds in sentimental depictions of wild animals in literature and art. ${ }^{27}$ His descriptions are authentic and true to life, a fine mix of poetry (and poetic license) ) $^{28}$ and pre-modern "scientific" observation of the natural world. The poet herewith subtly acknowledges that humans are part of the natural world, and confirms this explicitly when he lets God say (40:15): "Look at Behemoth, which I made along with you ..." And the purpose of this exposure to the wild animals by the Wise One is to allow Job (and humanity) to discern something of themselves in them and become wise too. ${ }^{29}$ There are familiar physical resemblances that humans and animals have in common, for example food, birthing and parenting. ${ }^{30}$ The labour pains that the mountain goats (ibexes) go through when birthing their young at the appropriate time (even though their "timing" remains a mystery), and parenting them in growing up until they are independent (39:1-4), humans can relate to, because (as mammals) they do the same. In regard to the gender of the animals where the strong males are conspicuous (raven, onager, auroch, war-horse, hawk, eagle, Behemoth and Leviathan), Clines interestingly comments on female gendering: "As in representations of the human world, the females fall into two stereotypical categories: the mother and the bad woman." 31 The lioness (lābî') providing for her young (38:39-40) is the good mother, compared to the bad female, the ostrich. She produces eggs and ignorantly leaves them unprotected and later on treats her offspring harshly. ${ }^{32}$ Emotionally-mentally there is also a recognisable

25 Clines, Job 38-42, 1133, says: "The central point of the animal descriptions seems rather to be that Yahweh has filled his created world with a vast variety of life forms, each with its own qualities and peculiarities, in which he evidently takes a delight." In his later work, Clines, "Worth of Animals," 101, seems to have an oversight for only indicating four birds and five mammals (there are six) and not mentioning the one reptile, the crocodile, amongst the different kinds of his list of eleven animals.

26 Clines, Job 38-42, 1091.

27 Frans B. M. de Waal, The Ape and the Sushi Master: Cultural Reflections of a Primatologist (New York: Basic Books, 2001), 71.

28 An example is the depiction of the ostrich as a "bad mother" (39:14-16) which is scientifically untrue. See footnote 32.

29 Habel, Finding Wisdom, 97; Carol Newsom, The Book of Job: A Contest of Moral Imaginations (New York: Oxford University Press, 2003), 235.

30 Milton Horne, "From Ethics to Aesthetics: The Animals in Job 38:39-39:30," RevExp 102 (2005): 136-137.

31 Clines, "Worth of Animals," 108.

32 Izak J. J. (Sakkie) Spangenberg, "Who Cares? Reflections on the Story of the Ostrich (Job 39.13-18)," in The Earth Story in Wisdom Traditions, ed. Norman C. Habel and Shirley Wurst (Sheffield: Sheffield Academic Press, 2001), 99, indicates the incorrectness of this folkloristic (and poetical) view in the light of modern ornithology. The alpha female's eggs are well protected in the centre of the nest surrounded by those of subordinate females, the latter to be snatched (or trampled) first by possible 
overlap between humans and the Joban animals so that humans can relate empathetically with their natural "kin."33 The "crying" (38:41 $\left.y^{e} \breve{s} a w w e ~ " \hat{u}{ }^{34}\right)$ of the hungry young ravens points to the emotion of anxiety or even fear of starvation, which is obviously not uncommon in nature. The human "laugh" $(s h q)$ is placed in the mouths of the onager (39:7), the ostrich (39:18), the horse (39:22) and the crocodile (41:21). "Laugh" in all these cases means "without fear" rather than scorn. ${ }^{35}$ The stem is also used with the meaning of "play" when describing the animals that share a habitat with the hippo (40:20) and the crocodile as a hypothetical pet for Job's daughters (40:29). The onager's laugh reflects his absence of fear of his potential captors (or hunters), ${ }^{36}$ as he wanders about in the salty steppe. "The ostrich is an image of pure heedless joy" ${ }^{37}$ as she flaps ${ }^{38}$ her

predators. The hatching of the eggs (by day by the brownish, inconspicuous female and by night by the black inconspicuous male) speaks of fine (and intelligent) instincts. Moreover, females shelter their young under their wings against rain and sun and will perform a distraction display to fool approaching predators, all to care for their young. See also Robert Gordis, The Book of Job: Commentary, New Translation and Special Studies, MorS 11 (New York: The Jewish Theological Seminary of America, 1978), 459; Marvin H. Pope, Job, Introduction, Translation, and Notes, AB 15 (New York: Doubleday, 1965), 261.

33 Apart from food, birthing and parenting that these animals have in common with humans, Horne, "From Ethics," 137, adds: “yet more significant to consider the poet's inclusion of 'anthropopathisms,' that is, the attributions of human emotions or cognition to animal behaviors." From modern ethology Marc Bekoff, "Wild Justice, Social Cognition, Fairness, and Morality," in A Communion of Subjects: Animals in Religion, Science and Ethics, ed. Kimberly C. Patton and Paul Waldau (New York: Columbia University Press, 2006), 473, provides a striking example of a greylag goose in grief over its lost partner, of its eyes sinking deep into their sockets and its head hanging. It is well-known that large-brained mammals (e.g. apes, elephants, dolphins) show signs of mourning but this example shows even birds have this capacity.

34 “The word used in 38:41 is 'cry out,' swy, and occurs as a Piel verbal form 21x, almost exclusively in Job and the Psalms ... the poet is establishing a clear parallel between animal and human suffering in relationship to God" says Horne, "From Ethics," 137-138.

35 Clines, Job 38-42, 1122, 1199.

36 Othmar Keel, Jahwes Entgegnung an Ijob: Eine Deutung von Ijob 38-41 vor dem Hintergrund der zeitgenössischen Bildkunst (Göttingen: Vandenhoeck \& Ruprecht, 1978), 75, 79.

37 Newsom, The Book of Job, 247. Newsom seems to over interpret the word for ostrich here in 39:13, re nānîm as signifying "cries of joy” compared to ya ănâ ("screecher") used for the ostrich elsewhere in the HB; so also are the interpretations of Norman C. Habel, The Book of Job, OTL (London: SCM Press, 1985), 525, and Samuel E. Ballantine, Job, SHBC (Macon: Smith \& Helwys Publishing, 2006), 664-665. Clines, Job 38-42, 1074, however, indicates that $r n n$ resembles in fact a rather harsh shout.

38 " עלס niph is here understood as 'be enjoyed, be delightful'” says Clines, Job 38-42, 1074. 
wings joyously to outrun her hunters on horseback. She not only "laughs" to celebrate her wild freedom, but similar to the ass, she has no fear for her human enemies. The horse fearlessly "laughs" in the midst of the battle (39:22), and confirms his excitement when "stamping $[r \stackrel{s}{s}]$ and raging $[\mathrm{rgz}]$ it swallows the ground” (39:24). ${ }^{39}$ Its cry of “Heag” (he 'ạh; 39:25) voices his satisfaction, not only confident and fearless in battle but also sensing the enemy's horses. ${ }^{40} \mathrm{He}$ is perfectly adapted for what he needs to do and fully and happily obliges. The young ones of the vulture "feast" on the blood of slain humans ${ }^{41}$ as they satiate their hunger (39:30). The NIV's translation of the Hebrew $y^{e} a l^{e}$ ' $\hat{u}$ ("they slurp") as "feasting" encapsulates the emotion of contentment. The well-adapted hippo is almost characterised by contentment or tranquillity, "lolling" 43 amongst the lotuses in the rivers with other animals that "play" nearby in the hills where he grazes. But a happy hippo can easily become savagely furious if an attempt is made to trap, catch and kill him as Egyptian hunters were known to do (40:24). ${ }^{44}$ And the "king of all beasts" (41:26), the crocodile, is a ferocious, undefeatable contender who fearlessly "laughs" at the multiple but feeble efforts of hunters to pin him down. ${ }^{45}$ In regard to humans' futile efforts to confront this almost largerthan-life, physically impressive animal, Clines further aptly remarks, "the message is, Let sleeping crocodiles lie." ${ }^{46}$ Early sparks of morality might also be sensed by the Joban poet. De Waal ${ }^{47}$ states that parenting can be considered as one of the early building blocks of all morality. The "instinctive" feeding and protection of their young, prompted through "emotional contagion" to act - the lion cubs, young ravens and young eagles - is clear in Job. And the bad ostrich mother evokes what "ought not to be," the neglect of your children in both the human and animal world.

A few preliminary, general comments on Job and the biophilic valuations mentioned above will suffice (and further illustrated below) - does the poet share these values? The utilitarian is not in the poet's view. The animals presented

39 Clines, Job 38-42, 1051.

40 Clines, Job 38-42, 1131. This is a fine example of onomatopoeia as is also the "snorting” ('ătîš $\bar{o} t \bar{a} y w$ ) of the crocodile in 41:10. The horse's cry here interestingly indicates its use of mirror neurons as it responds to surrounding sounds, similarly as a dog howling in response to a triggering sound, or visually imitating its owners' eating when it licks its chops.

41 Another nail in the coffin of human hubris by the poet.

42 Clines, Job 38-42, 1184.

43 Habel, Finding Wisdom, 108.

44 Keel, Jahwes Entgegnung, 133-135, 137-138.

45 Clines, Job 38-42, 1190, recaps succinctly: "Behemoth was indolent and unthreatening; Leviathan is nothing but violence and turmoil."

46 Clines, Job 38-42, 1161.

47 Frans B. M. de Waal, Primates (Princeton: Princeton University Press, 2006), 15. Bekoff, "Wild Justice," 467-472, argues that morality is fully present when animals (e.g. canines) signal rules to each other when at play, and cheaters are not tolerated. 
here are all wild (including the tamed horse retaining its wildness) which has no direct use for humans. The poet has the opposite view of the dominionistic or mastering of nature, namely subverting human hubris and showing Job that he (and humankind) is not the measure of all things, ${ }^{48}$ but that the natural world exists for itself in its own right. Although the moralistic has been touched upon, the text indicates no need for human custodianship and care as described above - nature looks after itself (or watched over by God). ${ }^{49}$ The naturalistic and ecologic-scientific values of the curiosity about nature, to deepen knowledge and stand in awe before nature's complexity is up front in the speeches. Habel even describes the speeches as "wisdom science" (see below). ${ }^{50}$ The humanistic (love for nature), aesthetic (fascination, awe and inspiration) and the symbolic (symbolising a greater truth) are conspicuous as the speeches reflect "poet's pleasure/divine delight." ${ }^{" 1}$ And the poet is also well-aware of the negativistic, the fearful avoidance and paying respect to dangerous wild animals (e.g. auroch, hippo and crocodile). In his insightful eighteenth century analysis of the sublime and the beautiful, Burke ${ }^{52}$ emphasises how the tremendous power of wild beasts (to cause pain and death) enhance the experience of awe, and interestingly refers to the Joban auroch as a "unicorn."

It indeed makes good sense that the ancient Joban poet chooses nature in all its richness to mirror before Job, to which humans intuitively relate because they are part of it. Nature becomes a means to think, feel and live by and finding oneself and one's place in the bigger scheme of things. It enhances a widening of horizons and the transcending of narrow anthropocentrism.

\section{DEVELOPMENTAL PSYCHOLOGY AND THE WILD ANIMALS OF THE DIVINE SPEECHES (OR: WHAT CAN WE LEARN FROM NATURE?)}

Developmental psychology is not only important to understand the developmental stages/phases that children go through but also important to understand adults, because they like children, are or should be lifelong learners. ${ }^{53}$ When Kellert therefore says that the exposure to nature and wild animals specifically, contributes to children's "health, emotional attachment, self

48 Adrianus van Selms, Job: A Practical Commentary, T\&I (Grand Rapids: W.B. Eerdmans, 1985), 146, 149.

49 Clines, "Worth of Animals," 111.

50 Habel, Finding Wisdom, 98.

51 Clines, "Worth of Animals," 108.

52 Burke, Philosophical Inquiry, 66. Apart from power, are also the notions of obscurity (darkness), vastness, infinity, suddenness, etc., contributing to the sublime experience.

53 Pascal Boyer, Religion Explained: The Evolutionary Origins of Religious Thought (New York: Basic Books, 2001), 106. 
concept, personal identity, self confidence, critical thinking, problem solving, curiosity, creativity, imagination," 54 it applies as much to adults as to children.

According to Melson ${ }^{55}$ views on wild animals changed during history, fluctuating between positive and negative. Increasing urbanisation has contributed to negative feelings about nature, mostly because "urbanites" feel isolated from nature. This, however, need not be so, as nature, even wild nature, is all around us. ${ }^{56}$ Wild animals are nowadays found on the edges of society (squirrels, rabbits, small antelope, feral cats or dogs, etc.), ${ }^{57}$ in our gardens (birds, insects) and in our homes (rodents, insects, etc.). There is therefore no excuse not to live with an attentive eye for the "wild" in our midst, and this can easily be utilised by parents to shape their children developmentally. However, both Melson and Kellert ${ }^{58}$ argue for an unstructured, unmediated (by parents) experience of nature for their self-development. Structured exposure is often reductionistic as they emphasise only certain behaviours of animals and often communicate rather narrow-minded, emotional-cultural scripts, for instance all snakes are "bad," sharks are human killers and so on.

Melson ${ }^{59}$ identifies four terrains of development that can be enhanced by exposure to nature: perceptual-cognitive development - this is the learning of new things to expand existing knowledge schemata and developing new ones. Melson subscribes to the Biophilia Hypothesis by indicating children's natural curiosity and affiliation with wild animals. Children intuitively prefer living things over artificial ones (e.g. animal toys). Children's knowledge increase through so-called naïve or folk-biology, arguing from humans to animals and categorising different biological kinds and their "essential" features ("biological essentialism” - e.g. what makes a crocodile different from a lion). ${ }^{60}$ Japanese children who have raised a gold fish for a year were far more conceptually advanced about describing its biological properties and extending this knowledge to other animals (frogs), than their peers who did not. The ascription of different "affordances" (physical and behavioural characteristics) to different

54 Stephen R. Kellert, "Introduction to the Special Issue on Children and Nature," JDP 4 (2009): 4.

55 Gail F. Melson, "Children and Wild Animals," in The Rediscovery of the Wild, ed. Peter H. Kahn, Jr., Patricia H. Hasbach and Jolina H. Ruckert (Cambridge: MIT Press, 2013), 97-99.

56 Melson, “Children,” 100.

57 An illuminating example (among many) are the well-adapted red foxes in the heart of London.

58 Melson, “Children,” 101-103; Kellert, “Introduction,” 4.

59 Melson, "Children," 108-114.

60 The cognitive psychologist Justin L. Barrett, Why Would Anyone Believe in God?, CSR (Walnut Creek: AltaMira, 2004), 3-6, describes this mental tool as a "living thing describer" as part of the so-called "describers" set of tools. The other two sets of tools are the (agency) "categorisers" and (social) "facilitators." 
animal species, prompts in the child "adaptive ways of responding;" 11 self-development - animal symbols in diverse cultures are often expressions of aspects of the self. If a child takes on an animal identity, for instance "growls" and pretends to be a tiger, this role-playing of a certain facet of the self (aggression) helps in the shaping of personal identity; ${ }^{62}$ social development - children (and adults) ascribe intentional agency to animals with their own feelings, desires, intentions and will, ${ }^{63}$ they are social agents. Contact with animals therefore enhances social skills. It also contributes to increased sociality with other humans as they share attention-giving to a pet ("social glue") ${ }^{64}$ or share game sightings in a game park; moral development - morality has been expanded from human-human to humananimal relationships. Melson ${ }^{65}$ indicates that a direct experience with living animals leads to less egocentric and dominionistic views towards more biocentric reasoning, even among those children that have just mastered biological reasoning. Melson concludes:

Animals, wild and non-wild, focus attention, aid perceptual discrimination, foster accommodation (in Piagetian terms, the acquisition of new conceptual categories), reflect and refract the self, act as social others, and prompt moral reasoning about other species and one's place in the universe. ${ }^{66}$

What has the pupil to learn from the wise teacher, God, in the divine speeches? In line with Job 28, Habel ${ }^{67}$ argues that we are meeting God as the sage in the divine speeches, the Wise One ${ }^{68}$ or as a "scientist." As a wisdom teacher he challenges Job to become a discerning "scientist" as well, and discover wisdom innate in the "design ( 'etsah) of the cosmos" (see Job 38:1-3). Habel indicates that wisdom technical terms are abundant in the speeches: ${ }^{69} \mathrm{Job}$

61 Melson, "Children," 113.

62 Melson, "Children," 114.

63 Barrett, Why Would Anyone, 3-6, refers to this mental capacity or "describer tool" as "Theory of Mind."

64 Melson, "Children," 117.

65 Melson, "Children," 119-120 (following Kellert and Kahn).

66 Melson, "Children," 122.

67 Habel, Finding Wisdom, 97, 98.

68 Clines, Job 38-42, 1087-1089, 1203, opposes the general understanding of Job according to the wisdom teacher:pupil model. He argues that the overall genre of the speeches is that of a disputation speech within the setting of a lawsuit. He, however, admits to the didactic even though presented in poetic form, and interestingly shows how there is a movement from the didactic (lion, raven, etc.) to the lyrical (with the focus on the hippo and crocodile), with far less rhetorical questions in the descriptions of Behemoth and Leviathan. In the end, however, Clines is sceptical that the didactic becomes a cover-up to hide the real character of God, who teaches Job nothing, at least nothing about justice, which was Job's initial problem. And therefore, Job gives up on God in his second reply to the deity and wants to carry on with his life.

69 Habel, Finding Wisdom, 100-102, 105, 108. 
38:18 "Have you discerned (bin) the expanses of the earth, tell me if you know (yada') all this;" 38:24-25 "Where is the way (derek) that disperses lightning ... and made the way (derek) for the thunderstorm?" Job 38:36 "Who put wisdom (chokma) in the clouds? Who gave discernment (bina) to my pavilion?”; 39:26 "Is it by your discernment (bina) that the hawk soars, spreading its wings to the South?"; and about Behemoth in 40:19 "He is the first of El's ways [derek]," also expressing that this massive creature is rather a symbol of wisdom than of chaos, ${ }^{70}$ depicted hyperbolically rather than mythological. ${ }^{71}$ Job is almost introduced to the workings of the universe like an ignorant child by the superior wise God, or in terms of developmental psychology, mediated exposure to nature.

About the animal kingdom Job learns remarkably much in terms of "biology" (how they look like physically) and also "ethology" (their "ways" or behaviour). The poet expands far more than necessary to introduce Job to the wonderful mysteries of nature to expand his conceptual knowledge. ${ }^{72}$ He learns about the bodies of animals, the ibexes that give birth as mammals (39:1-4) almost like their human counterparts, and their offspring resemble in essence their adult parents (the lion cubs, young ravens, eagle chicks). He learns that ostriches lay eggs (39:14-17) to ensure future generations and hippos mate to procreate (40:17). ${ }^{73}$ The immense bodily strength of the auroch, war-horse, hippo and crocodile is up front. He learns about the food they eat: lions their meaty prey (38:39) and crows and eagles their carrion (38:41; 39:29-30). The onager is a herbivore similar to the hippo (and auroch). Job is introduced to diverse habitats that these animals occupy to meet their needs - lions have dens and thickets, onagers have salty plains and mountains, ostriches live in the open field, aurochs do not belong in human habitats (and the wild horse perhaps also), hawks and eagles nest in unreachable places, and hippos and crocodiles live in water and nearby land. And Job is taught about their mental lives as well - they have strong instincts to feed and protect their young (except the ostrich according to folklore), to give birth at the right time, to migrate at the appropriate time (hawk) and to fiercely defend their instinct for freedom. Animals have emotions to which humans can relate and make sense of. These animals are also presented as pedagogic models, typical of wisdom literature, from whom Job (and his readers)

70 Habel, Finding Wisdom, 107-108, here changes his view from his 1985 commentary viewpoint, Book of Job, 564, a viewpoint also subscribed to by Newsom, Book of Job, 247, 251. Clines, Job 38-42, 1191, argues in the same vein about Leviathan (and Behemoth): "It seems best to see it as a real creature depicted with mythological features or overtones ... not ... a symbol of evil (as Keel, 143-44) or of chaos (as Newsom)."

71 Clines, Job 38-42, 1186 (following Alter).

72 Clines, "Worth of Animals," 108. And in similar vein Horne, "From Ethics," 130, argues: "For example, in 39:1-4 ... verse 4 extends the description even further to include the growth and maturation of young ones, well beyond the realm of concern defined by the discrete knowledge of birth times.”

73 Van Selms, Job, 202. 
may select to enrich aspects of his own self. O’Connor recaps the poet's urge to widen horizons when he says: "The speeches urge us to be like the animals and the monsters, Behemoth and Leviathan, wild, fearlessly ourselves, exuberantly alive." 74 Newsom and Hartley ${ }^{75}$ similarly argue to accept life in its fullness and even to participate to a certain extent in God's wild, wondrous and raging creativity; to become transformed by this exposure to uninhibited, sublime wild nature.

On social development there is not much except for the relationship between Job and God. On moral development, to transcend egocentrism towards biocentrism when exposed to nature, the text is rich. Clines ${ }^{76}$ repeatedly emphasises the poet's decentring of human interests only, the subversion of unbridled anthropocentrism, nicely encapsulated earlier in Job 38:26 "to bring rain on a land uninhabited, on the unpeopled desert."77 On Behemoth, for instance, as representative of all animals, Clines comments, "what it signifies for him [Job] as a human being is that a substantial part of the created order, if not the greater part, has nothing to do with his interests;"78 humans do not occupy the primary place, they are but a small, living speck in the rich biodiversity of nature, they are not the so-called crown of creation. And similarly also Habel ${ }^{79}$ when describing the wild ox's unwillingness to "serve' ('abad)" humans, is almost an inverse of the mandate of humans to "'have dominion' (rada)" in Gen $1: 26-28$. Job's reaction towards the end of the speeches (42:1-6) indicates that the pupil has become wise and learned about cosmic wisdom, that God's cosmic wisdom order or "blue-print" works otherwise than the rule-bound, human moral order, ${ }^{80}$ and notably about the human's place in it. Clines, ${ }^{81}$ however, differs

74 Kathleen M. O’Connor, "Wild, Raging Creativity: Job in the Whirlwind," in Earth, Wind and Fire: Biblical and Theological Perspectives on Creation, ed. Carol J. Dempsey, Mary M. Pazdan (Collegeville: Liturgical Press, 2004), 54.

75 Newsom, Book of Job, 234-258; John E. Hartley, The Book of Job, NICOT (Grand Rapids: WB Eerdmans, 1988), 487.

76 Clines, "Worth of Animals," 104, 111, 113.

77 An eloquent translation by Clines, Job 38-42, 1049.

78 Clines, "Worth of Animals," 111.

79 Habel, Finding Wisdom, 104; see also Norman C. Habel, “'Is the Wild Ox Willing to Serve you?' Challenging the Mandate to Dominate,” in The Earth Story in Wisdom Traditions, ed. Norman C. Habel and Shirley Wurst, EBCS 3 (Sheffield: Sheffield Academic Press, 2001), 188.

80 Clines, Job 38-42, 1184, confirms especially Behemoth as a symbol for God not being rule-bound when he rightly asks: "Can it be that Behemoth, rather than humanity, that is his masterpiece because Behemoth so well represents God's freedom - his freedom to refuse rules and rationality and principles of utility, even aesthetics?” In similar vein Newsom, Book of Job, 247, speaks about the anarchic freedom of these animals. See also Habel, Finding Wisdom, 113.

81 Clines, Job 38-42, 1224. See also footnote 66. 
about Job's learning and ascribes a far more reserved, even disappointed (cynical?) reaction on Job's side (see below).

\section{EMOTIONAL PSYCHOLOGY AND THE WILD ANIMALS OF THE DIVINE SPEECHES (OR: WHAT FEELINGS ACCOMPANY THE EXPOSURE TO NATURE?)}

Myers and others state that emotions form a central component in meaningmaking, being goal-oriented, attention focused, arouse (physiologically) to action and have social value. ${ }^{82}$ Emotions and moods are "states," the first very brief and the last prolonged, whilst sentiments (the established result of a repeated emotion) and affective traits (e.g. shyness) can be described as "dispositions." The (stereotypic) structural view of emotions as universal in terms of experience, expression and arousal is contested nowadays by the functionalist view of emotions being flexible, responsive and enhancing performance. In regard to the last-mentioned view, to which Myers and others subscribe, the contextual experience of an emotion rests on three functions: a cognitive assessment or "primary appraisal" of a situation, physiological arousal and a communicative/social function to influence others. ${ }^{83}$

Applying these insights to obtain a multi-dimensional measurement of the emotional experience of wild animals in a zoo, ${ }^{84}$ Myers and others conducted an experiment on 279 adults (of differing ages and gender), to lay bare their feelings towards a gorilla, okapi and a snake. Interestingly, the participants did not differ that much in their judgements in terms of gender and age, but notably in their appraisal of the different animals. The gorilla and okapi evoked far more positive emotional assessments than the snake. The experiment's findings across animals were:

Specifically, sense of beauty, respect, wonder, peacefulness, special privilege, caring and attraction were all reported at fairly high frequencies, with modest variations across animals. Other emotions were felt at moderate intensities: amusement, sense of connection, love, sympathy, and surprise. Concern, fear, disgust, anger and embarrassment were so low as not to be part of the profile of expected emotions. ${ }^{85}$

82 Myers, Saunders, and Birjulin, “Emotional Dimensions,” 299.

83 Myers, Saunders, and Birjulin, “Emotional Dimensions,” 302-305.

84 Myers, Saunders, and Birjulin, "Emotional Dimensions," 301, note that there are few studies on the emotional effect of wild animals on humans outside of zoos, that is in the wild.

85 Myers, Saunders, and Birjulin, “Emotional Dimensions,” 315. 
Of all the emotions respect, wonder, sympathy and surprise came out top, with fear and disgust at the lowest level. It is clear that people generally and intuitively revere wild animals.

Elaborating on the "moral, spiritual and aesthetic emotion" of awe, Keltner and Haidt ${ }^{86}$ provide an illustrative example, that of Arjuna in the Baghavadgita story (part of the Hindu epic Mahabarata). Arjuna, the hero, had to go into battle with his rivals for the kingdom, but lost nerve. The god Krishna steps in and tries to persuade Arjuna, with arguments from the workings of the universe, to continue with the battle. Arjuna demands to see the universe for himself and Krishna provides him with a "cosmic eye" to see God and the universe first hand. Arjuna's reaction is telling: "Things never seen before have I seen, and ecstatic is my joy; yet fear-and-trembling perturb my mind.” This reaction almost echoes that of Job after the creational tour by God, except for the ecstatic joy if one follows Cline's interpretation of Job's reserved reaction (see below).

Taking cognisance of the insights of different disciplines on awe, Keltner and Haidt say:

Theorists agree that awe involves being in the presence of something powerful, along with associated feelings of submission. Awe also involves difficulty in comprehension, along with associated feelings of confusion, surprise, and wonder. ${ }^{87}$

Vastness (physical [e.g. size] or social [e.g. prestige]) usually correlated with power, and accommodation or the difficulty to understand something "awesome/terrific" within one's existing cognitive structures (leading to confusion, feelings of humiliation and smallness, powerlessness, also "enlightenment" when mental structures expand), are the two core features of awe. The Joban commentator, Newsom, almost echoes this description of the experience of awe and the sublime, and adds that it leads not only to a cognitive crisis but indeed of one's subjectivity itself. And the aftermath is a newly "elated" self. ${ }^{88}$ Five additional features "flavour" the awe experience with their accompanying feelings, namely threat (fear), beauty (aesthetic pleasure), ability (admiration), virtue (elevation or a "warm and pleasant feeling in the chest"), supernatural causality (joy or fear). ${ }^{89}$ Keltner and Haidt argue that primordial awe stems from the emotional experience of a subordinate to a powerful leader,

86 Dacher Keltner and Jonathan Haidt, “Approaching Awe, a Moral, Spiritual, and Aesthetic Emotion,” $\operatorname{Cog} E 17$ (2003): 297-298.

87 Keltner and Haidt, “Approaching Awe,” 303.

88 Newsom, Book of Job, 236-237. The notion of "elation” is described by Burke, Philosophical Inquiry, 57, as "astonishment," the sigh of relief that is experienced after escaping a life-threatening danger.

89 Keltner and Haidt, “Approaching Awe,” 303-306. 
characterised by passivity, heightened attention and imitation of this leader. ${ }^{90}$ This kind of awe becomes generalised/extended to for instance buildings, operas or nature. If extended towards non-powerful people, awe becomes "admiration" rather than awe in the strict sense of the word. ${ }^{91}$ When extended to nature awe leads to "[a] diminished self, the giving way of previous conceptual distinctions (e.g. between master and servant) and the sensed presence of a higher power" and the transcending of previous knowledge. ${ }^{92}$ Moreover, the experience of awe transforms people and gives them a new direction and goal in life. ${ }^{93}$

Is there awe in Job? The emotional-mental capacities of the animals have been touched on above, allowing humans to recognise something of themselves in these expressions of joy, excitement, contentment, fear, anger and so on. And these depictions become subtle invitations to Job to join in and become part of the divine cosmic design that God's animals so comfortably are at ease with. They ask no questions and enjoy being alive and accept what nature has to offer them. Clines writes illuminatingly on the poet's and his Yahweh's "delight in his creatures."94 Yahweh "rejoices" in the freedom of the laughing onager and ostrich. And even Leviathan, a fearful "monster" in the eyes of humans, is praised. Clines insightfully names the last few descriptive verses of this formidable animal (41:25-26) an "encomium."95 Humour contributes to the poet's and Yahweh's pleasure by showing the impossibility of domesticating the wild ox, or of subduing Behemoth with kitchen implements: "Can it be captured with a fork, can you pierce its nose with hooks" (40:24). ${ }^{96}$ And the same applies to the "laughable" attempts to capture Leviathan. It is remarkable how the animals depicted here match the additional features (and accompanying emotions) just mentioned, contributing to (and "flavouring") the experience of awe: "threat" and accompanying fear are clear in confrontations with the aurox, hippo and crocodile; "beauty" and aesthetic pleasure are aptly portrayed by the running of the (not so gifted) ostrich, flapping her wings, "all beauty (39:13) but no sense" says Clines; 97 "ability" evoking admiration is conspicuous in the warhorse and the way he knows how to do battle. And with this same animal also "virtue" or "strength of character"98 as he fearlessly storms into battle, evoking elevation as he incites/inflames others (humans included) to do likewise;

90 The acknowledgement of authority is biologically based, says Keltner and Haidt, “Approaching Awe," 306. From cognitive psychology, Barrett, Why Would Anyone, 36 , describes the mental tool for recognising authority as the "social status monitor," which is part of the set of mental tools called the social facilitators.

91 Keltner and Haidt, “Approaching Awe,” 309.

92 Keltner and Haidt, “Approaching Awe,” 310.

93 Keltner and Haidt, “Approaching Awe,” 312.

94 Clines, "Worth of Animals," 109.

95 Clines, Job 38-42, 1200.

96 Clines, "Worth of Animals," 110.

97 Clines, "Worth of Animals," 108.

98 Keltner and Haidt, “Approaching Awe,” 305. 
"supernatural causality" with both its glorifying and terrifying affects are succinctly demonstrated by God's two special creatures, his "masterpiece" ( $r \bar{e}$ 'šit ; 40:19), Behemoth, ${ }^{99}$ and Leviathan, the "king of all proud beasts." These are animals close to God's heart, something of himself as creator is manifested in these formidable creatures, in their size, power and temperament they resemble something of the "godly." 100 If awe at its core has to do with hierarchy, of subordinates looking up to a powerful superior person, phenomenon or animal, these two creatures are most likely to deserve awe and respect. Although the resemblances with the Joban animals were emphasised earlier (to learn from), it is especially with these two creatures that their differences with humans are emphasised (to respect them). Clines ${ }^{101}$ also emphasises how the poet subverts human standards of dislike and disgust towards these animals which are of no use to them. Have we not just seen that reptiles like snakes, and presumably their close kin, crocodiles, evoke a natural fear in humans? To the Joban poet, however, God gives them a special place in his wise design of the universe.

Has Job the character grasped the impetus towards awe of the divine speeches? Yes, he has, demonstrates Habel succinctly with Job's two reactions to God: 40:4, "I am unworthy - how can I reply to you? I put my hand over my mouth..." Habel paraphrases appropriately, in light of the above: "I am small”"102 admitting to God as the greater power. As we have seen, this is the awe reaction of a subordinate to a superior, and the loss of words indicates the difficulty to accommodate this widening of horizons after the exposure to the wonders of nature. Job's second reaction is in the same vein, the previous talkative Job has little to say: 42:5, "I have heard of you with my ears but now my eyes see you." This indicates an "authentic" experience of $\operatorname{God}^{103}$ where Job has discerned (perhaps better "sensed") the greater reality of God's design but not an admittance of any guilt. But here scholars' views differ on Job’s reaction, which has been one of the most enigmatic sections of the book to interpret. Habel for instance, understands Job’s interpretation as positive: “Job 'observes' God in nature ... Job sees God in all the mysteries revealed in the cosmos. God, like wisdom, is innate in the cosmos." 104 According to Habel Job has been "converted." ${ }^{105}$ He has seen the light and he retracts his case against God (42:6),

99 This is a "plural of majesty" meaning "supreme beast," says Clines, "Worth of Animals,” 112.

100 The animals in the speeches reflect more of his omnicompetence than his omnipotence, remarks Clines, Job 38-42, 1089.

101 Clines, "Worth of Animals," 113.

102 Habel, Finding Wisdom, 106. "קלל is 'be light,' and so 'be contemptible,’” says Clines, Job 38-42, 1137.

103 Clines, Job 38-42, 1206, 1216.

104 Habel, Finding Wisdom, 113.

105 When Habel, Finding Wisdom, 118, imaginatively paraphrases Job’s voice, he says: "After discerning wisdom as the cosmic blueprint in the design of creation, the innate 
but without admitting guilt or wrongdoing. Clines, however, ascribes a far more reserved, even cynical reaction to Job. The "light" Job has seen is rather that he has given up on God, a rejection of the divine address. ${ }^{106}$ God has not answered anything whatsoever that Job has summoned him for, the question of justice. Instead, God has side-stepped this issue completely. ${ }^{107}$ When Job retracts his case it is out of hopelessness, ${ }^{108}$ he is never going to get an answer from this God. He now only wants to get on with his life, with "his family and his farm." 109 If Clines is correct then this vast creational tour has by-passed Job and meant nothing to him, unless he appreciates something of nature with his "farming" endeavour. It seems as if the skilful poet has lured its readers to embrace nature as good to think, feel and live by, but his main character disappointingly (and anthropocentrically) declines, as this was never his issue. Despite Job's reaction, Clines nevertheless acknowledges and subscribes to the poet's delight in the natural world and his decentring of anthropocentrism. ${ }^{110}$ Perhaps this is what good literature is all about, allowing for multiple meanings and choices.

\section{E ENVIRONMENTAL PSYCHOLOGY AND THE WILD ANIMALS OF THE DIVINE SPEECHES (OR: RESTORATION AND CONTEMPLATION THROUGH NATURE)}

The environmental psychology couple, Stephen and Rachel Kaplan is known for developing Attention Restoration Theory (ART). ${ }^{111}$ ART has to do with the resting and restoration of the directed (voluntary) attention mental mechanism, very simplistically described as our "concentration." The last-mentioned allows us to conduct our work effectively, to focus and to function in an emotionally balanced way. Humans also have another mental mechanism, namely an undirected (involuntary) attention mechanism to "switch over to" and to rest our focused attention when this limited resource becomes fatigued. Involuntary attention becomes activated notably through "fascination" with nature: beautiful sunsets, cloud formations, natural landscapes with greenery and water, animals, and so on. Nature, however, has to meet the requirements or properties of being away, compatibility, soft fascination and extent. These properties intersect and

code in all the domains of nature and the life force embedded in all living things, I came to understand that wisdom is a cosmic network, a deep ecology in the universe. I was converted."

106 Clines, Job 38-42, 1224.

107 Clines, Job 38-42, 1203.

108 Clines, Job 38-42, 1211.

109 Clines, Job 38-42, 1221-1222. The enigmatic sentence about dust and ashes is translated by Clines as follows: "I accept consolation for my dust and ashes," where 'al should be understood as "for" or "on account of" and not "upon" as it is usually translated. Job here decidedly ends his mourning over all his losses, notably that of his children (see also 2 Sam 13:39, Jer 31:15, Ezek 32:31). See again also footnote 68.

110 Clines, "Worth of Animals," 103.

111 Kaplan and Kaplan, Experience of Nature. 
complement one another to effect restoration and overall human well-being. Being away or "getting away from it all" implies both a physical and psychological escape from one's familiar, and often boring, working and living environment. To be in "another world" implies the awareness of "cognitive content different from the usual." 112 Compatibility is all about fitting into nature to fulfil a specific purpose/need or to satisfy a human inclination. ${ }^{113}$ This tallying with nature comes quite naturally, even for those of us who have become fully urbanised because of our interconnectedness with nature. Nature is where we evolved from, where we have been moulded over many years into the beings we are and allowed us to adapt successfully to diverse surroundings. It therefore makes good sense that there is a "special resonance" between humans and the natural environment. ${ }^{114}$ Soft fascination, or the effortless "undramatic"115 attention-grabbing effect of inspiring natural scenes has been indicated above. It is especially fascination that enhances the wandering of the mind, which often translates into a spiritual consciousness of wonderment and awe, of being connected to some greater, unseen reality. ${ }^{116}$ Extent implies order, structure, coherence or interrelatedness of the different elements of a natural setting. If a natural setting does not signal safety, free movement and aid memory in finding one's way, it will be intuitively avoided. ${ }^{117}$ Extent also implies a rich and interesting content or scope, luring the mind that there is more to explore and discover than a first glance impression of a natural setting. ${ }^{118}$ This quality's evocation of a connectedness also to something conceptually larger, "another world," works in partnership with the previous ones and leads to contemplation and reflection. ${ }^{119}$

Except for compatibility (purpose/goal of achieving something in nature, e.g. a survival trip) the divine speeches meet all the other requirements of ART. Job is being "taken away" by God on this vast creational tour and exposed to "cognitive content different from the usual” (as just explained), an "escape” from his depressing, outcast circumstances. The poet and his character God has gone

112 Kaplan and Kaplan, Experience of Nature, 189.

113 Kaplan and Kaplan, Experience of Nature, 185.

114 Kaplan and Kaplan, Experience of Nature, 193.

115 Stephen Kaplan, "The Restorative Benefits of Nature: Toward an Integrative Framework,” JEP 15 (1995): 174.

116 Kaplan and Kaplan, Experience of Nature, 195, 197.

117 Stephen Kaplan, "Meditation, Restoration and the Management of Mental Fatigue," EnvB 33 (2001): 3-5; Raymond de Young, "Restoring Mental Vitality in an Endangered World: Reflections on the Benefits of Walking," EcoPs 2 (2010): 18.

118 A minute but interesting suburban garden can have the same uplifting effect as a visit to a large nature reserve.

119 See Hendrik Viviers, “Gardens as 'Partners' in Contemplation: Reading the Stories of the First Eden (Genesis 2-3) and a Restored Eden (Song of Songs) through the Lens of Attention Restoration Theory,” JSem 25 (2016): 347-370, for a more extensive application of this approach to some biblical texts. 
to great lengths to convince Job of the fine order and structure of the cosmos and of its rich and interesting interconnected/interdependent bio-diversity. Nature as depicted here clearly meets the requirement of "extent." Fascination and awe have been indicated above already, experienced by the poet, God and Job. And Job's reaction shows that reflection ${ }^{120}$ has happened. He "grasps something" of God's wise design ( 'eșa) of the universe and his place in the bigger scheme of things. The previously angered and aggressive Job has become "restored" through this vast tour through the wonders of creation, if one accepts, for instance, Habel's understanding of Job's “conversion” and probably the reaction of most readers too. But even if one, for instance, accepts Clines' interpretation of Job's cynical rejection of God, reflection has taken place. He now knows that his rational issues of justice are going to stay unanswered.

\section{F CONCLUSION}

The focus on the worth of wild animals in the Joban divine speeches is something unique in the HB. ${ }^{121}$ The appreciation of wild nature by this pre-scientific but nevertheless well-informed wisdom author, resonates with the value of the exposure to the natural world that the few exemplary psychologies (there are obviously more) have laid bare. The Biophilia Hypothesis has highlighted our innate bond with nature, our intuitive valuation thereof and the impoverishment of the human psyche with the loss of the bio-diversity of our planet. The Joban author acknowledges this bond (physically, emotionally and morally) as he takes Job and the reader on this vast and bio-diverse creational tour. Developmental psychology has emphasised the cognitive, self, social and moral development of children (and adults implied) when exposed to the natural world. The Joban author has grasped this when he lets God as a wise teacher (even if this teaching happens within a court case) expand his pupil's "biological” and "ethological” knowledge, urges him to discover something of himself and the "godly" in the wild and free animals and aims to help him to transcend his egocentrism and anthropocentrism (even though he declined towards the end $a$ la Clines). Emotional psychology has shown that the emotions of awe, wonderment, respect, sympathy and surprise feature prominently in the human:animal contact. Job certainly experiences awe as he stands before a higher power and design that are beyond his grasp. His "few words" towards the end confirm his difficulty to understand, whether he "converts," acknowledging God's embedded wisdom in the cosmos (e.g. Habel), or gives up on God for not being rationally (a human-

120 Clines, Job 38-42, 1203, says the following on the purpose of the shift from the didactic to the lyrical in the divine speeches, with the focus on Behemoth and notably Leviathan, "an understanding that comes through indirection, a worldview that arises from a wondering (rather than the analytical) contemplation of reality.” This is what the poet wants to achieve, although his main character Job does not oblige, according to Clines.

121 Clines, "Worth of Animals," 113. 
centred trait) answered on justice (e.g. Clines). Environmental psychology has shown how nature through the properties of "being away," compatibility, fascination and extent, contributes to overall human well-being. Except for compatibility, the divine speeches reflect something of all these properties.

Both modern psychology and the Joban divine speeches confirm in tandem that nature is good to think, feel and live by. The first does this by empirically researching the good effect of nature on humans and the second celebrates this through inspiring ancient poetry.

\section{BIBLIOGRAPHY}

Ballantine, Samuel E. Job. SHBC. Macon: Smith \& Helwys Publishing, 2006.

Barrett, Justin L. Why Would Anyone Believe in God? CSR. Walnut Creek: AltaMira, 2004.

Bekoff, Marc. “Wild Justice, Social Cognition, Fairness, and Morality.” Pages 461480 in A Communion of Subjects: Animals in Religion, Science and Ethics. Edited by Kimberly C. Patton and Paul Waldau. New York: Columbia University Press, 2006.

Boyer, Pascal. Religion Explained: The Evolutionary Origins of Religious Thought. New York: Basic Books, 2001.

Burke, Edmund. A Philosophical Inquiry into the Origin of our Ideas of the Sublime and the Beautiful. Edited by James T. Boulton. London: Routledge and Kegan Paul, 1967.

Clines, David J. A. Job 38-42. WBC 18B. Nashville: Thomas Nelson, 2011. . "The Worth of Animals in the Divine Speeches of the Book of Job." Pages 101-113 in Where the Wild Ox Roams: Biblical Essays in Honour of Norman C. Habel. HBM 59. Edited by Alan H. Cadwallader and Peter L. Trudinger. Sheffield: Sheffield Phoenix Press, 2013.

De Young, Raymond "Restoring Mental Vitality in an Endangered World: Reflections on the Benefits of Walking." Ecopsychology 2/1 (2010): 13-22.

De Waal, Frans B. M. The Ape and the Sushi Master: Cultural Reflections of a Primatologist. New York: Basic Books, 2001. . Primates and Philosophers: How Morality Evolved. Princeton: Princeton University Press, 2006.

Gordis, Robert. The Book of Job: Commentary, New Translation and Special Studies. MorS 11. New York: The Jewish Theological Seminary of America, 1978.

Habel, Norman C. The Book of Job. OTL. London: SCM Press, 1985. . "'Is the Wild Ox Willing to Serve you?' Challenging the Mandate to Dominate.” Pages 179-189 in The Earth Story in Wisdom Traditions. EBCS 3. Edited by Norman C. Habel and Shirley Wurst. Sheffield: Sheffield Academic Press, 2001. . Finding Wisdom in Nature: An Eco-Wisdom Reading of the Book of Job. EBCS 4. Sheffield: Sheffield Phoenix Press, 2014.

Hartley, John E. The Book of Job. NICOT. Grand Rapids: WB Eerdmans, 1988. Horne, Milton. "From Ethics to Aesthetics: The Animals in Job 38:39-39:30” RevExp 102 (2005): 127-142. 
524 Viviers, "Why Nature is Good," OTE 30/2 (2017): 503-524

Kaplan, Rachel and Stephen Kaplan. The Experience of Nature: A Psychological

Perspective. Cambridge: Cambridge University Press, 1989.

Kaplan, Stephen. "The Restorative Benefits of Nature: Toward an Integrative Framework.” JEP 15 (1995): 169-182.

. "Meditation, Restoration and the Management of Mental Fatigue." EnvB 33 (2001): 1-16.

Keel, Othmar. Jahwes Entgegnung an Ijob: Eine Deutung von Ijob 38-41 vor dem Hintergrund der zeitgenössischen Bildkunst. Göttingen: Vandenhoeck \& Ruprecht, 1978.

Kellert, Stephen R. "The Biological Basis for Human Values of Nature.” Pages 42-69 in The Biophilia Hypothesis. Edited by Stephen R. Kellert and Edward O. Wilson. Washington: Shearwater Books, 1993.

. "Introduction to the Special Issue on Children and Nature.” JDP 4 (2009): 3-5.

Keltner, Dacher and Jonathan Haidt. "Approaching Awe, a Moral, Spiritual, and Aesthetic Emotion.” $\operatorname{Cog} E$ 17/2 (2003): 297-314.

Melson, Gail F. “Children and Wild Animals.” Pages 93-118 in The Rediscovery of the Wild. Edited by Peter H. Kahn, Jr., Patricia H. Hasbach and Jolina H.

Ruckert. Cambridge: MIT Press, 2013.

Myers, Olin E. Jr., Carol D. Saunders, and Andrej A. Birjulin. "Emotional Dimensions of Watching Zoo Animals: An Experience Sampling Study Building on Insights from Psychology.” Curator 47/3 (2004): 299-321.

Newsom, Carol. The Book of Job: A Contest of Moral Imaginations. New York: Oxford University Press, 2003.

O’Connor, Kathleen M. "Wild, Raging Creativity: Job in the Whirlwind.” Pages 4856 in Earth, Wind and Fire: Biblical and Theological Perspectives on Creation. Edited by Carol J. Dempsey and Mary M. Pazdan. Collegeville: Liturgical Press, 2004.

Pope, Marvin H. Job, Introduction, Translation, and Notes. AB 15. New York: Doubleday, 1965.

Spangenberg, Izak J. J. (Sakkie). "Who Cares? Reflections on the Story of the Ostrich (Job 39.13-18).” Pages 92-102 in The Earth Story in Wisdom Traditions. Edited by Norman C. Habel and Shirley Wurst. Sheffield: Sheffield Academic Press, 2001.

Van Selms, Adrianus. Job: A Practical Commentary. T\&I. Grand Rapids: W.B. Eerdmans, 1985.

Viviers, Hendrik. "Gardens as 'Partners' in Contemplation: Reading the Stories of the First Eden (Genesis 2-3) and a Restored Eden (Song of Songs) through the Lens of Attention Restoration Theory.” JSem 25/1 (2016): 347-370.

Wilson, Edward O. "Biophilia and the Conservation Ethic." Pages 31-41 in The Biophilia Hypothesis. Edited by Stephen R. Kellert and Edward O. Wilson. Washington: Shearwater Books, 1993.

Prof Hendrik Viviers is a lecturer at the Department of Religion Studies at the University of Johannesburg.Email: hviviers@uj.ac.za. 